\title{
Relation of Red Cell Distribution Widht with Ascending Aortic Diameter in Bicuspid Aortic Valve Patients
}

\author{
Biküspit Aort Kapak Hastalarında Kırmızı Hücre Dağılım Aralığı \\ lle Asendan Aort Çapı Arasındaki llişki
}

\section{Abdullah Nabi Aslan', Serdal Baştuğ', Muhammed Cihad Çelik', Hacı Ahmet Kasapkara², Mehmet Murat Yiğitbaşı², Yunus Emre Özbebek², Engin Bozkurt ${ }^{2}$}

'Ataturk Education and Research Hospital, Department of Cardiology, Ankara, Turkey 2 Yıldırım Beyazıt University Faculty of Medicine, Department of Cardiology, Ankara, Turkey

Yazışma Adresi / Correspondence:

Abdullah Nabi Aslan

Angora homes, Sazyolu avenue, Number:6, Çankaya Street: Mutlukent, Postal code: 06800City/Country: Ankara/Turkey T: +90 $5327801305 \quad$ E-mail: drnabiaslan@hotmail.com

Geliş Tarihi / Received : 04.02.2018 Kabul Tarihi / Accepted : 10.04.2018

\footnotetext{
Abstract

Objective Red cell distribution widht (RDW) and neutrophil to lymphocyte ratio (NLR) plays a significant role in assessing the severity and progression of some cardiac conditions. Bicuspid aortic valve (BAV)-associated aortopathy is common and its progression for individual patients is difficult to predict. In this study, we aimed to investigate the association between serum levels of RDW, NLR and ascending aortic diameter (AAd) in BAV patients. Sakarya Med J, 2018, 8(2):327-335 )

Materials and This is a descriptive and methodologic study which included a total of 182 consecutive patients with a BAV. Complete blood counts were Methods analyzed for RDW level and NLR. Patients were divided into two groups based on their AAd and patients with AAd of 3.9 and above were included in group 1 , while those below 3.9 in group 2 .

Results NLR was significantly higher in group 1 patients than those in group 2. RDW levels were similar. In univariate correlation analysis, a positive correlation was found between AAd and RDW and NLR in group 1 patients. In multivariate logistic regression analysis, RDW (odds ratio $(\mathrm{OR}): 1.78,95 \%$ confidence interval $(\mathrm{CI}): 1.36-2.44, \mathrm{P}=0.01)$ remained as independent correlates of AAd in the patient population. Receiver operating characteristic (ROC) curve analysis revealed that a RDW measurement $>13.0 \%$ predicted ascending aort dilatation (AAD) with a sensitivity of $58 \%$ and a specificity of $79 \%$

Conclusion RDW and NLR are positively correlated with AAd in BAV patients with AAD. These markers may point out the role of inflammation both in the pathogenesis and progression of AAD in these patients.

Keywords Bicuspid aortic valve, ascending aortic diameter, red cell distribution widht, ascending aortic dilatation
}

\section{$\ddot{\mathbf{O z}}$}

Amaç Kırmııı kan hücresi dağııım genişliği (KHDG) ve nötrofil lenfosit oranı (NLO) bazı kardiyak durumların ciddiyetinin ve progresyonunun değerlendirilmesinde önemli bir rol oynar. Biküspit aortik kapak (BAK)- ilişkili aortopati sık görülür ve progresyonunu bireysel hastalarda tahmin etmek zordur. Bu çalışmada, biz BAK hastalarında KHDG'nin serum düzeyleri ve NLO ile asendan aort çapı (AAÇ) arasındaki ilişkiyi araşıırmayı amaçladık. ( Sakarya Tıp Dergisi, 2018, 8(2):327-335 ).

Gereç ve Toplamda 182 ardışı BAK hastası bu tanımlayıcı ve metodolojik çalışmaya alındı. KHDG düzeyi ve NLR için tam kan sayımı incelendi.

Yöntem Hastalar AAÇ'lerine göre 2 gruba ayrıldı ve AAÇ 3.9 ve üzeri olan hastalar grup 1, 3.9' un altında olan hastalar ise grup 2'ye dahil edildi.

Bulgular NLO grup 1 hastalarında grup 2'dekilere kıyasla anlamlı olarak daha yüksekti. KHDG seviyeleri benzerdi. Tekli korelasyon analizinde, AAÇ ile KHDG ve NLO arasında anlamlı pozitif korelasyon saptandı. Çoklu regresyon analizinde RDW'nin (odds ratio (OR): 1.78, 95\% confidence interval $(\mathrm{Cl}): 1.36-2.44, \mathrm{P}=0.01)$ asendan aort dilatasyonunun bağımsız bir belirteci olduğu belirlendi. Receiver operating characteristic (ROC) analizinde KHDG için > 13.0\% sınır değerinin asendan aort dilatasyonu tanısı için \%58 duyarllık ve \%79 özgüllüğe sahip olduğu bulundu.

Sonuç KHDG ve NLO asendan aort dilatasyonu olan BAK hastalarında AAÇ ile pozitif koreledir. Bu belirteçler bu hastalarda asendan aort dilatasyonunun hem patogenezi hem de progresyonunda inflamasyonun rolü olduğunu gösterebilir.

Anahtar Biküspit aortik kapak, asendan aort çapı, kırmızı kan hücresi dağıım genişliği, asendan aort dilatasyonu 
Sakarya Med J.

2018;8(2):327-335

\section{Introduction}

Bicuspid aortic valve (BAV) represents the most frequent congenital heart malformation and as such it may be subject to valvular stenosis, regurgitation or infective endocarditis. ${ }^{1,2}$ Even in the absence of echocardiographically relevant valve dysfunction, it may be associated with ascending aorta dilatation (AAD) at different anatomical levels. ${ }^{3}$ Dilatation of the tubular ascending aorta is the most frequent form of bicuspid aortopathy and simultaneously an issue of extensive and controversial debate. Moreover, even patients with functionally normal BAVs have been shown to present with larger aortic diameters both at baseline and during follow-up when compared with their controls. ${ }^{4}$ The diversity of bicuspid aortopathy is closely related to the bicuspid valve morphology as well as the type of valvular dysfunction, while the progression rates of aortic dilatation may differ substantially. ${ }^{5,6}$

Red cell distribution widht (RDW) shows the variability in erythrocytes volume in the peripheral blood. Neutrophil to lymphocyte ratio (NLR), as an oxidative stress and proinflammatory marker, has recently emerged as a useful indicator to predict cardiovascular risk and adverse outcomes ${ }^{7}$. Both RDW and NLR are easily available laboratory parameters and can be quickly measured in complete blood count (CBC) test. The prognostic importance of these markers have been reported in a novel study which show an association of RDW and NLR in patients with AAD before. ${ }^{8}$ The correlation of RDW and NLR with inflammatory markers has showed these markers to be indicators of chronic inflammation in disease progression with high levels resulting in worse outcome.9

The relation of plasma levels of RDW and NLR with ascending aortic diameter (AAd) has not been established yet in patients with BAV. Therefore, in this study we aimed to investigate the association between these parameters and AAd in BAV patients.

\section{Materials and Methods}

\section{Patient selection}

At this descriptive and methodologic study we prospectively enrolled consecutive patients who were performed transthoracic echocardiographic examination and were diagnosed to have BAV between March 2015 and July 2017. Basic data and clinical history of these patients concerning age, gender, hypertension, diabetes mellitus, hyperlipidemia, cardiovascular diseases and smoking were noted. Patients with acute and/or chronic inflammatory disease, connective tissue disease associated with AAD (Marfan syndrome, Behçet disease etc.), a malignancy, hematological disease, anemia, alcohol abuse, a history of renal and liver disease were excluded from this study. The study was approved by the local ethics committee and informed consents of all subjects were obtained.

\section{Echocardiographic examination}

The patients with BAV were re-examined with transthoracic echocardiography by an independent and experienced cardiologist who was blinded to the clinical or laboratory findings of the study population. The echocardiographic examinations were carried out using a 2.5 to $3.5 \mathrm{MHz}$ transducer with the Vingmed System 7 (Vivid 7, GE, Horten, Norway). Two-dimensional (2-D) measurements were performed in the parasternal long-axis view with the patient in left lateral position. The left atrium (LA) diameter, interventricular septum (IVS) and posterior wall (PoW) thicknesses, LV end-diastolic diameter (LVEDD) and LV end-systolic diameter (LVESD) were obtained using the 
M-mode echocardiographic tracings under the guide of 2-D imaging. The left ventricular ejection fraction (LVEF) was calculated according to the biplane modified Simpson's rule. The morphology of the aortic valve was defined in the parasternal short axis view. The 2-D echocardiographic criteria for BAV included the partial or complete fusion of 2 of the aortic valve leaflets resulting in either a partial or complete absence of a functional commissure between the fused leaflets. 10 Aortic velocity $(\mathrm{m} / \mathrm{s})$ was measured from apical 4 chambers using continuous wave Doppler. 2-D measurements of the aortic root were made at end-diastole in the parasternal long-axis views using the leading edge to leading edge technique in the views showing the largest aortic diameters at three levels as: (1) annulus, (2) sinus of Valsalva and (3) proximal ascending aorta.

Ascending aortic dilatation was determined on demonstration of aortic enlargement relative to the expected aortic diameter based on age and body size adjusted nomograms as recommended by the American Heart Association (AHA) guidelines. ${ }^{11}$

\section{Laboratory measurements}

Venous blood samples were drawn into EDTA-treated or plain tubes according to hospital protocol from all participants at morning hours after a fasting period of 12 hours. Glucose, urea, creatinine and lipid profile were determined by standard methods. CBC testing utilized clinical laboratory methods (Coulter LH 780 Hematology Analyzer, Beckman Coulter Ireland Inc; Mervue, Galway, Ireland) for total white blood cell (WBC), neutrophil, lymphocyte and platelet counts, haemoglobin level, mean platelet volume (MPV) and RDW. The reference range for RDW was between 11.0$14.5 \%$. Baseline NLR was measured by dividing the neutrophil count to lymphocyte count.

\section{Statistical analysis}

All statistical analyses were performed with IBM SPSS 19.0 software (IBM Corp., New York, NY, USA). Data were tested for normal distribution using the Kolmogorov-Smirnov test. Data are expressed as mean value \pm standard deviation for continuous variables, as well as numbers with percentage for categorical variables. Unpaired two-sided t-test was used to compare continuous variables between the study subgroups. Categorical variables were analysed by 2 test or Fisher's exact test as appropriate. Correlations between two continuous variables were assessed with Pearson's test. Binary logistic regression analysis was used to find the possible independent association between dilation of the ascending aorta and clinical parameters. P-values of 0.05 or less were considered statistically significant.

\section{Results}

A total of 182 consecutive BAV patients were enrolled into this study. The mean age of the patients was $41.2 \pm 12.4$ (range 19-75) years and 68\% of them was male. Among 182 patients, 45 with AAD were included into group 1 whereas remaining patients were included into group 2 . The clinical and demographic characteristics of both groups are demonstrated in Table 1. There were no significant differences between the groups with respect to body mass index, smoking rate, heart rate, systolic and diastolic blood pressure and incidence of hypertension and diabetes mellitus. The mean age of BAV patients with AAD was $47 \pm 12$ (range 22-65) years which was much higher than that of the BAV patients without AAD ( $<<0.001)$. The rate of male patients were also significantly higher in group 1 compared to group 2 patients (91\% vs 67\%, respectively, $p=0.002$ ). Moreover, the incidence of hyperlipidemia was significantly higher in group 1 patients when it was
Sakarya Med J.

2018;8(2):327-335

ASLAN et al.

Relation of Red Cell Distribution Widht with Ascending

Aortic Diameter In Bicuspid Aortic Valve Patients 
compared to those in group 2 (51\% vs 34\%, respectively, $p=0.018)$.

Table 1. Clinical and demographic characteristics of the patient groups with bicuspid aortic valve

\begin{tabular}{|c|c|c|c|}
\hline Variables & Group $1(\mathrm{n}=45)$ & Group $2(\mathrm{n}=137)$ & $P$ value \\
\hline Age (years) & $47 \pm 12$ & $39 \pm 11$ & $<0.001$ \\
\hline Male, $(\%)$ & 91 & 67 & 0.002 \\
\hline Body mass index $\left(\mathrm{kg} / \mathrm{m}^{2}\right)$ & $22.1 \pm 6.3$ & $21.9 \pm 4.1$ & 0.415 \\
\hline Heart rate, bpm & $74 \pm 12$ & $75 \pm 14$ & 0.695 \\
\hline Smoking rate (\%) & 40 & 35 & 0.234 \\
\hline Systolic blood pressure, mmHg & $116 \pm 34$ & $114 \pm 26$ & 0.204 \\
\hline Diastolic blood pressure, $\mathrm{mmHg}$ & $75 \pm 16$ & $76 \pm 18$ & 0.780 \\
\hline Hypertension (\%) & 12 & 11 & 0.902 \\
\hline Diabetes mellitus (\%) & 10 & 12 & 0.740 \\
\hline Hyperlipidemia (\%) & 51 & 34 & 0.018 \\
\hline \multicolumn{4}{|l|}{ Echocardiography } \\
\hline LVEDD (cm) & $5.1 \pm 0.6$ & $4.6 \pm 0.4$ & $<0.001$ \\
\hline LVESD $(\mathrm{cm})$ & $3.4 \pm 0.8$ & $2.8 \pm 0.4$ & $<0.001$ \\
\hline IVS (cm) & $1.1 \pm 0.21$ & $1.0 \pm 0.18$ & 0.058 \\
\hline PoW (cm) & $1.0 \pm 0.18$ & $1.0 \pm 0.13$ & 0.017 \\
\hline LA (cm) & $3.5 \pm 0.4$ & $3.4 \pm 0.4$ & 0.117 \\
\hline $\operatorname{LVEF}(\%)$ & $55 \pm 16$ & $63 \pm 3$ & $<0.001$ \\
\hline Annulus diameter $(\mathrm{cm})$ & $2.29 \pm 0.19$ & $2.12 \pm 0.13$ & $<0.001$ \\
\hline Sinus of Valsalva diameter $(\mathrm{cm})$ & $3.66 \pm 0.13$ & $3.14 \pm 0.9$ & $<0.001$ \\
\hline Ascending aortic diameter $(\mathrm{cm})$ & $4.12 \pm 0.27$ & $3.31 \pm 0.32$ & $<0.001$ \\
\hline Moderate-severe AR (\%) & $6(13)$ & $10(14)$ & \\
\hline Moderate-severe AS (\%) & $1(2)$ & $3(4)$ & \\
\hline
\end{tabular}

Data presented as mean \pm standard deviation. AR: Aortic regurgitation, AS: Aortic stenosis, IVS : interventricular septum thickness; LA : left atrium diameter; LVEDD : left ventricular end-diastolic diameter; LVEF : left ventricu-

lar ejection fraction, LVESD : left ventricular end-systolic diameter; PoW: posterior wall thickness

When echocardiographic parameters were compared, it was detected that LVEDD, LVESD, PoW, aortic annulus, ascending aorta and sinus of Valsalva diameters were significantly higher whereas LVEF was significantly lower in group 1 patients than those in group 2. However, LA diameter and IVS thickness were similar between groups. Mean AAd was $4.12 \pm 0.27 \mathrm{~cm}$ (range 3.9-4.9 cm) in the AAD group and $3.31 \pm 0.32 \mathrm{~cm}$ (range 2.1-3.8 cm) in patients without AAD. Only 6 patients in the AAD group (13\%) had moderate to severe aortic regurgitation.

The laboratory parameters of the patient groups were listed in Table 2. Accordingly, WBC count, neutrophil count and NLR ( $2.5 \pm 1.6$ vs $2.1 \pm 0.7$, respectively, $p<0.001)$ were significantly higher in patients with AAD than those without. However, there was not statistically significant differences in terms of haemoglobin, mean platelet volume, RDW levels and platelet count between the groups. When, lipid profiles were compared, total cholesterol, HDL cholesterol and TG levels were found to be similar whereas LDL cholesterol level was significantly higher in group 1 patients than those in group 2 ( $127 \pm 44 \mathrm{vs} 107 \pm 35 \mathrm{mg} / \mathrm{dL}$, respectively, $p=0.004)$. Receiver operating characteristic (ROC) curve analysis revealed that a RDW measurement higher than $>13.0 \%$ predicted AAD with a sensitivity of $52 \%$ and a specificity of $79 \%$ (AUC $0.553, p=0.027$ ) in the study population (Figure). 


\begin{tabular}{|l|c|c|c|}
\hline \multicolumn{4}{|l|}{ Table 2. Laboratory parameters of the study population and subgroups } \\
\hline Parameters & Group 1 $(\mathrm{n}=45)$ & Group 2 $(\mathrm{n}=137)$ & P value \\
\hline White blood cell count $(103 / \mu \mathrm{L})$ & $8.7 \pm 2.9$ & $6.7 \pm 1.6$ & $<0.001$ \\
\hline Neutrophil count $(103 / \mu \mathrm{L})$ & $5.5 \pm 2.4$ & $4.1 \pm 1.3$ & $<0.001$ \\
\hline Lymphocyte count $(103 / \mu \mathrm{L})$ & $2.4 \pm 8.8$ & $2.0 \pm 5.7$ & 0.002 \\
\hline Neutrophil/lymphocyte ratio & $2.5 \pm 1.6$ & $2.1 \pm 0.7$ & 0.043 \\
\hline Haemoglobins $(\mathrm{g} / \mathrm{dL})$ & $14.0 \pm 1.8$ & $14.4 \pm 2.1$ & 0.358 \\
\hline Platelet $(103 / \mu \mathrm{L})$ & $249 \pm 70$ & $268 \pm 92$ & 0.209 \\
\hline Mean platelet volume, fL & $10.8 \pm 1.0$ & $11.0 \pm 7.2$ & 0.854 \\
\hline Red cell distribution widht, \% & $15.8 \pm 8.5$ & $15.2 \pm 6.1$ & 0.631 \\
\hline Total cholesterol $(\mathrm{mg} / \mathrm{dL})$ & $199 \pm 35$ & $185 \pm 45$ & 0.078 \\
\hline LDL Cholesterol $(\mathrm{mg} / \mathrm{dL})$ & $127 \pm 44$ & $107 \pm 35$ & 0.004 \\
\hline HDL Cholesterol $(\mathrm{mg} / \mathrm{dL})$ & $50 \pm 10$ & $49 \pm 15$ & 0.516 \\
\hline Triglyceride (mg/dL) & $125 \pm 58$ & $157 \pm 200$ & 0.308 \\
\hline Data presented as mean \pm standard deviation. $\mathrm{HDL}:$ high density lipoprotein; LDL : low density lipoprotein \\
\hline
\end{tabular}

In univariate correlation analysis, there were positive correlation between RDW levels and LVEDD ( $r: 0.30, p=0.04$ ), IVS ( $r: 0.61, p<0.001)$, PoW ( $(r: 0.52, p<0.001)$ and AAd ( $(r: 0.52, p<0.001)$ in group 1 patients. RDW levels were positively correlated with LVEDD in group 2 patients as well. However, correlation between RDW levels and AAd was only demonstrated in BAV patients with AAD that is group 1 (Table 3 ).

\begin{tabular}{|c|c|c|c|}
\hline Parameters & $\begin{array}{l}\text { All patients }(n=182) \\
\text { Co-efficient ( } p \text { value })\end{array}$ & $\begin{array}{c}\text { Group } 1(n=45) \\
\text { Co-efficient ( } p \\
\text { value) }\end{array}$ & $\begin{array}{c}\text { Group } 2 \\
(n=137) \\
\text { Co-efficient } \\
\text { ( } p \text { value })\end{array}$ \\
\hline Age & $-0.105(0.160)$ & $0.119(0.436)$ & $-0.153(0.077)$ \\
\hline BMI & $0.184(0.588)$ & $0.126(0.572)$ & $0.221(0.654)$ \\
\hline Total cholesterol & $-0.182(0.311)$ & $-0.387(0.112)$ & $-0.011(0.911)$ \\
\hline LDL cholesterol & $-0.125(0.123)$ & $-0.366(0.219)$ & $-0.042(0.658)$ \\
\hline HDL cholesterol & $0.092(0.255)$ & $-0.221(0.164)$ & $0.162(0.087)$ \\
\hline Triglycerides & $-0.033(0.682)$ & $0.273(0.084)$ & $-0.062(0.512)$ \\
\hline LVEDD & $-0.115(0.123)$ & $0.303(0.043)$ & $-0.271(0.001)$ \\
\hline LVESD & $-0.082(0.272)$ & $0.267(0.076)$ & $-0.224(0.009)$ \\
\hline IVS & $0.137(0.068)$ & $0.619(<0.001)$ & $0.012(0.890)$ \\
\hline PoW & $0.144(0.054)$ & $0.525(<0.001)$ & $0.047(0.592)$ \\
\hline LA & $0.006(0.941)$ & $0.254(0.092)$ & $-0.055(0.530)$ \\
\hline LVEF & $-0.035(0.636)$ & $-0.122(0.424)$ & $-0.034(0.700)$ \\
\hline AAd & $0.005(0.945)$ & $0.528(<0.001)$ & $-0.050(0.567)$ \\
\hline \multicolumn{4}{|c|}{$\begin{array}{l}\text { AAd : Ascending aorta diameter; BMI : Body mass index; IVS : Interventricular septum thickness; LA : Left } \\
\text { atrium diameter; LVEDD : Left ventricular end-diastolic diameter; LVEF : Left ventricular ejection fraction; LVESD } \\
\text { : Left ventricular end-systolic diameter; PoW: Posterior wall thickness; RDW: Red cell distribution widht }\end{array}$} \\
\hline
\end{tabular}

In univariate binary logistic regression analysis, male gender, WBC and RDW levels, NLR and presence of hyperlipidemia were associated with AAD. In multivariate binary logistic regression analysis, only increased levels of RDW (odds ratio (OR): 1.78, 95\% confidence interval (CI): 
Bicuspid aortic valve is a common congenital disorder and a significant proportion of such patients develop cardiovascular complications over time. The pathogenesis of BAV is unclear. Genetic abnormalities, including neural crest abnormalities, deficiencies in endothelial-derived nitric oxide synthase, fibrillin-1 deficiencies, increased matrix metalloproteinase (MMP) levels, and enhanced hemodynamic stress on the ascending aortic wall as a result of turbulent flow over the malformed valve, are implicated in the development of BAV disease and associated aortic abnormalities. ${ }^{12}$ Associated aortopathy is an important but still poorly understood problem that is frequently detected in BAV patients. More than one third of patients with a BAV have AAD. ${ }^{13}$ Current guidelines state that it is reasonable to replace the ascending aorta in patients with BAV undergoing aortic valve replacement surgery if the AAd is larger than $5.5 \mathrm{~cm}$. However, if there are additional risk factors (family history of aortic dissection or aortic growth rate $\geq 0.5 \mathrm{~cm}$ per year) for dissection and low surgical risk, surgery is recommended in AAd above $5.0 \mathrm{~cm} .14$ Below these thresholds, near follow-up with transthoracic echocardiography and if needed computed tomography is recommended. However, the availability of these techniques are not always possible and therefore some new predictors may be required for follow-up of such patients with BAV and AAD. Here, we found a positive correlation of AAd with NLR and RDW in BAV patients with AAD. In addition, we demonstrated RDW as an independent correlates of AAD in these patients. These laboratory parameters are easily available almost in all health centers and can be evaluated by only one tube $\mathrm{CBC}$ assay. These findings may at least give a small clue about AAd in BAV patients with $A A D$ and for that reason may be utilized as a routine assay at follow-ups of such patients.

Red blood cell distribution width is obtained from a standard $\mathrm{CBC}$. It is a measure of the variability in size of circulating erythrocytes and is indicated as the coefficient of variation of the erythrocyte size. ${ }^{15}$ It is routinely analyzed in CBC and utilized as a useful marker for differential diagnosis of anemia. ${ }^{16,17}$ Researchers attribute oxidative stress and inflammation as the actual underlying mechanism in the predictive role of RDW as a potential prognostic marker in various diseases. ${ }^{18,19}$ There have been an increasing number of studies regarding the association between RDW and inflammation and inflammatory markers. Moreover, in a study increased levels of RDW levels was reported in patients with AAD.8 Although we did not find a significant difference in RDW levels in patient groups with and without $A A D$, we found a significant correlation between RDW and AAd in BAV patients with AAD.

Proinflammatory status can be measured by using various biochemical and haematological markers. Although there are novel disease-specific biomarkers, most of these are time consuming and expensive. NLR is an important measure of proinflammatory status. It is cost-effective, readily available, and can be calculated with a simple CBC assay. The relationship between NLR and AAD have been demonstrated before in hypertensive patients. ${ }^{7}$ However, until now, these relationship had not been showed in BAV patients.

\section{Study Limitations}

This is not a large scale study. Therefore, we can only observe a relationship between study parameters and AAd but can not establish a causal relationship. In addition, only hemoglobin levels were measured in our study; the factors that may be associated with erythrocyte homeostasis such as the levels of iron, ferrition, folat, vitamin B12 and other inflammatory mediators were not assessed.
Sakarya Med J.

2018;8(2):327-335

ASLAN et al.

Relation of Red Cell Distribution Widht with Ascending

Aortic Diameter In Bicuspid Aortic Valve Patients 


\section{Conclusions}

There is a positive correlation between RDW, NLR and AAd in BAV patients with AAD. RDW and NLR as a marker of chronic low-grade inflammation may play a role in the pathogenesis of aneurysm of the ascending aorta in BAV patients. High levels of RDW concurrent with an increase in AAd in BAV patients with AAD may indicate an ongoing subtle inflammatory process that cause progression of AAD in these patients. However, further large scale studies are needed to confirm our results and extrapolate whether the levels of RDW and NLR can be used as a marker of the disease progression and prognosis in these patients.

\section{Conflict of Interest}

The authors declare no conflicts of interest. 
1. Roberts WC. The congenitally bicuspid aortic valve. A study of 85 autopsy cases. Am J Cardiol 1970;26:72-83.

2. Sabet HY, Edwards WD, Tazelaar HD, Daly RC. Congenitally bicuspid aortic valves: a surgical pathology study of 542 cases (1991 through 1996) and a literature review of 2,715 additional cases. Mayo Clin Proc 1999; 74:14-26.

3. Nistri S, Sorbo MD, Marin M, Palisi M, Scognamiglio R, Thiene G. Aortic root dilatation in young men with normally functioning bicuspid aortic valves. Heart 1999;82:19-22.

4. Beroukhim RS, Kruzick TL, Taylor AL, Gao D, Yetman AT. Progression of aortic dilation in children with a functionally normal bicuspid aortic valve. Am J Cardiol 2006;98:828-30.

5. Kang JW, Song HG, Yang DH, Baek S, Kim DH, Song JM et al. Association between bicuspid aortic valve phenotype and patterns of valvular dysfunction and bicuspid aortopathy: comprehensive evaluation using MDCT and echocardiography. JACC Cardiovasc Imaging 2013;6:150 61.

6. Della Corte A, Bancone C, Buonocore M, Dialetto G, Covino FE, Manduca Set al. Pattern of ascending aortic dimensions predicts the growth rate of the aorta in patients with bicuspid aortic valve. JACC Cardiovasc Imaging 2013;6:1301-10

7. Cem Ö, Yilmaz S, Korkmaz A, Fahrettin T, Sahin I, Demir V. Evaluation of the neutrophil-lymphocyte ratio in newly diagnosed nondiabetic hypertensive patients with ascending aortic dilatation. Blood Press Monit. 2016 Aug;21(4):238-43.

8. Güngör B, Özcan KS, Özpamuk Karadeniz F, Uluganyan M, Ekmekçi A, Alper AT, et al. Red cell distribution widht is increased in patients with ascending aortic dilatation. Turk Kardiyol Dern Ars. 2014 Apr;42(3):22735.

9. Förhécz Z, Gombos T, Borgulya G, Pozsonyi Z, Prohászka Z, Jánoskuti L. Red cell distribution width in heart failure: prediction of clinical events and relationship with markers of ineffective erythropoiesis, inflammation, renal function, and nutritional state. Am Heart) 2009;158:659-66.

10. Roberts WC. The congenitally bicuspid aortic valve: a study of 85 autopsy studies.Am J Cardiol. 1970;26(1):72-83.

11. Hiratzka LF, Bakris GL, Beckman JA, Bersin RM, Carr VF, Casey DE Jr, et al. 2010 ACCF/AHA/AATS/ACR/ASA/SCA/SCAl/SIR/STS/SVM guidelines for the diagnosis and management of patients with Thoracic Aortic Disease: a report of the American College of Cardiology Foundation/ American Heart Association Task Force on Practice Guidelines, American Association for Thoracic Surgery, American College of Radiology, American Stroke Association, Society of Cardiovascular Anesthesiologists, Society for Cardiovascular Angiography and Interventions, Society of Interventional Radiology, Society of Thoracic Surgeons, and Society for Vascular Medicine. Circulation 2010;121:266-69.
12. Fedak PW, Verma S, David TE, Leask RL, Weisel RD, Butany J. Clinica and pathophsiological implications of a bicuspid aortic valve.Circulation. 2002;106(8):900-04.

13. Michelena HI, Desjardins VA, Avierinos JF, Russo A, Nkomo VT, Sundt TM, et al. Natural history of asymptomatic patients with normally functioning or minimally dysfunctional bicuspid aortic valve in the community. Circulation 2008;21:2776-84.

14. Hiratzka LF, Creager MA, Isselbacher EM, Svensson LG, Nishimura RA, Bonow RO, et al. Surgery for Aortic Dilatation in Patients With Bicuspid Aortic Valves: a statement of clarification from the American College of Cardiology/American Hear Associatin Task force on Clinical Practice Guidelines. J Am Coll Cardiol. 2016 Feb 16;67(6):724-31.

15. K. Clarke, R. Sagunarthy, and S. Kansal. RDW as an additional marker in inflammatory bowel disease/undifferentiated colitis. Digestive Diseases and Sciences 2008:53:2521-23.

16. Mawlana W, Donia A, Elamrousy D. Relation between red cell distribution width and left ventricular function in children with heart failure. ISRN Pe diatrics 2014:2014:234835.

17. Kojima T, Yasuhara J, Kumamoto T, Shimizu H, Yoshiba S, Kobayash T, Sumitomo N. Usefulness of the red blood cell distribution width to predict heart failure in patients with a Fontan circulation. Am J Cardiol 2015; $116: 965-68$

18. Polat V, Iscan S, Etli M, El Kilic H, G ursu O, Eker E, Ozdemir F. Red cell distribution width as a prognostic indicator in pediatric heart disease and after surgery. Biomed Res Int 2014;2014:681679.

19. Rodriguez-Carrio J, Alperi-Lopez M, Lopez P, Alonso-Castro S, Carro Esteban SR, Ballina Garcia F), Suarez A. Red cell distribution width is associated with endothelial progenitor cell depletion and vascularrelated mediators in rheumatoid arthritis. Atherosclerosis 2015;240:131-36.
2
$\pi$
$\pi$
$\pi$
$\pi$
$\pi$
$m$
$z$
$n$
$\pi$
$\omega$

Sakarya Med 2018;8(2):327-335

ASLAN et al. Relation of Red Cell Distribution Widht with Ascending Aortic Diameter In Bicuspid Aortic Valve Patients 